https://doi.org/10.37208/tgn27118

\section{Millport's Easter Class, 1939}

\author{
P.G. Moore \\ 32 Marine Parade, Millport, Isle of Cumbrae \\ KA28 0EF
}

E-mail: p.geoff.moore@gmail.com

Some years ago I published a photograph of a teachertraining course in marine zoology held at Millport in 1914 (Moore, 2012). Recently an interesting series of Marine Station class photographs from 1939 came to my attention. At the recent members' evening of Cumbrae Historical Society, a member (Mrs Sue Forrest) exhibited (inter alia) eight snapshots taken that year and she kindly agreed to loan them to me to see what historical information I might glean from them. Three were identified on the reverse, as "Mar '39" and relate mainly to the Easter zoology class held at the Marine Station that year. Two, however, were identified as "Nov. '39" and the remainder simply as "Millport '39", one of which had the locality noted as "Fairlie Sands". All were annotated in ink by the same hand.

In the Annual Report of the Scottish Marine Biological Association for 1938-39 (SMBA, 1939) we read the following: "From 23rd-30th March Mr C.W. Parsons conducted the junior Easter class with the assistance of Dr J.D. Robertson. This class was a large one of 30 students from the University of Glasgow [possibly a second-year group: Roger Downie, pers. comm.], three from Cambridge and one from Aberdeen." (see Figs. 13 ). It may be a forlorn hope to expect to be able to identify the students, but I am confident that the man in the front row (slightly right of centre) in the somewhat faded Fig. 1, labelled on the reverse "Millport Zoology Class outside Marine Station, Mar. 1939”, is the genial Richard Elmhirst (see Moore, 2008), the Station's Director who always took a prominent role in teaching student groups. It seems likely that the gentleman sitting cross-legged to his right is Charles Wynford Parsons. Parsons, a staff member of the Department of Zoology, University of Glasgow, was a vertebrate specialist; he wrote on the South American toad (Ceratophrys) (Parsons, 1932a) and penned the report on penguin embryos collected during the research cruises of RSS Discovery (Parsons, 1932b). Fig. 2 is captioned "Dr Robertson and 2 students". They are seen larking about on one of Millport's piers (Keppel? Millport Old Pier?), perhaps waiting for a boat or ferry trip. James Duncan ("J.D." to all) Robertson (1912-1993), who eventually became a Professor in the University of Glasgow, was a distinguished physiologist, with a particular interest in the inorganic composition of body fluids of marine invertebrates. He also worked on vertebrates and had an influential theory on the origin of vertebrates based on this work (Robertson, 1957). Fig. 3 captures a subset of the same group relaxing at the foot of the Deil's Dyke at the rear of the Marine Station. It is interesting to observe the formal outdoor attire of male students at the time: gabardine mackintoshes and trilby hats (see Fig. 2), and to note ruefully that their world was shortly about to be turned upside down by the outbreak of hostilities with Germany.

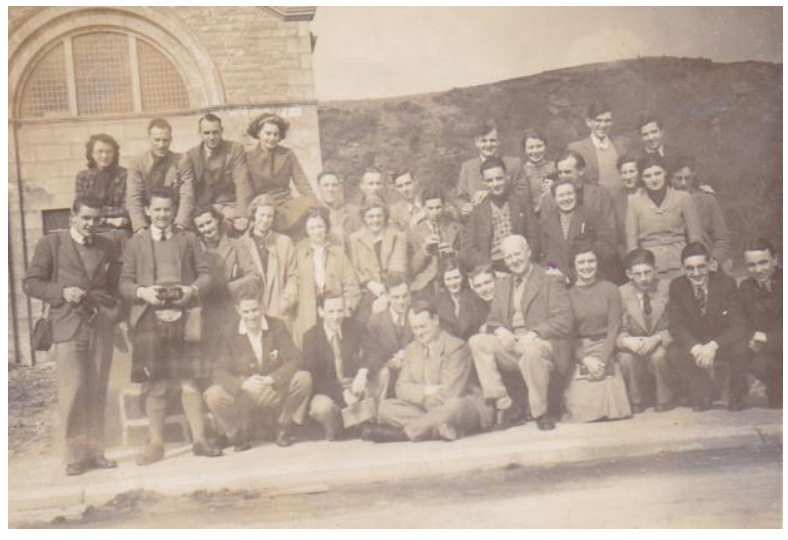

Fig. 1. "Millport Zoology Class outside Marine Station, Mar. 1939". (Photo: S. Forrest)

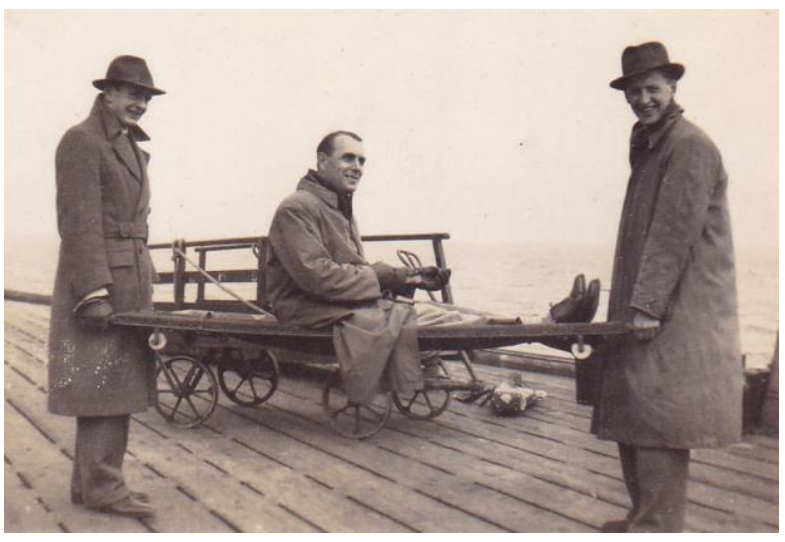

Fig. 2. "Millport March 1939 Dr Robertson \& 2 students". (Photo: S. Forrest)

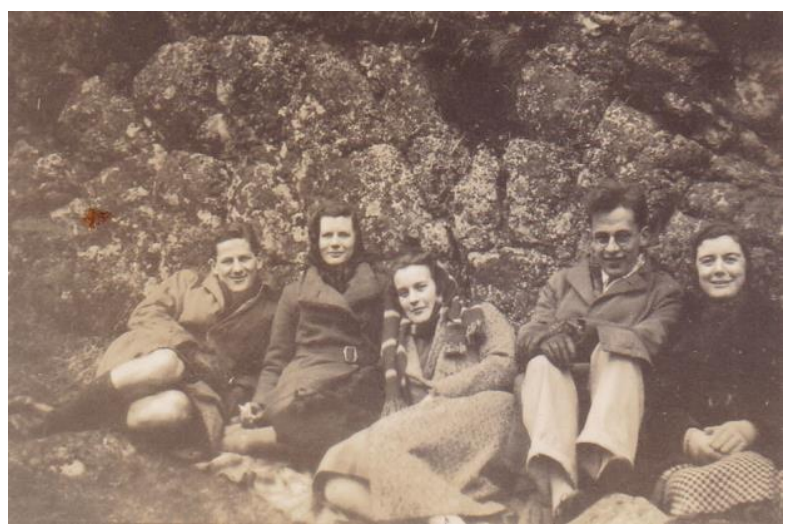

Fig. 3. "Millport Mar. '39”. (Photo: S. Forrest) 
Fig. 4 is inscribed on the reverse "Millport, Dr Colson \& students Nov '39" and looks as if they were just arriving by steamer. I can find no information relating to this party in the Annual Report of the Scottish Marine Biological Association for 1938-39 or 1939-1940 (SMBA, 1939, 1940). She may be Dr Barbara Colson who was a botanist (fungal cytologist), latterly of the University of Manchester.

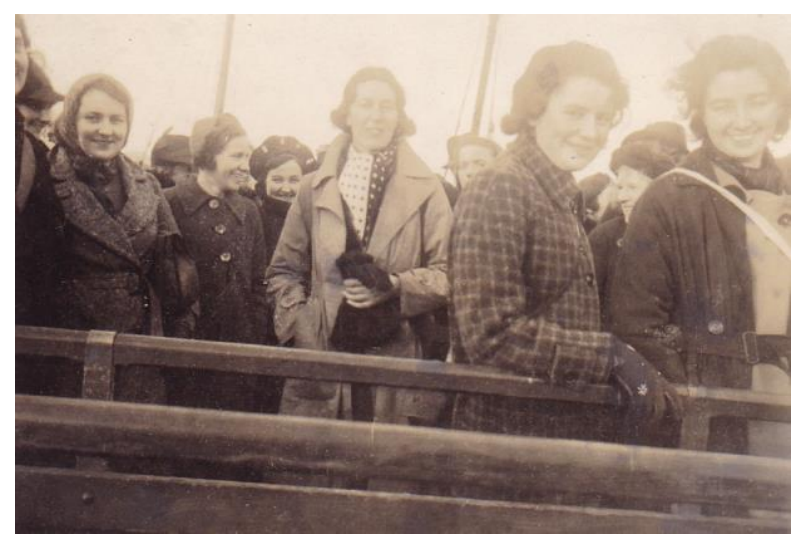

Fig. 4. "Millport Dr Colson \& students Nov. '39". (Photo: S. Forrest)

\section{ACKNOWLEDGEMENTS}

I am grateful to Sue Forrest for allowing me access to her "Old Millport" photograph collection, and to Professor Roger Downie for his helpful comments.

\section{REFERENCES}

Moore, P.G. (2008). An appreciation of Richard Elmhirst, J.P., F.L.S. (1884-1948), the 'other' Cumbrae naturalist. The Scottish Naturalist 120, 543.

Moore, P.G. (2012). A photograph of a teacher-training course in marine zoology at Millport (1914). The Glasgow Naturalist 25(4), 132-133.

Parsons, C.W. (1932a). Habits of the toad, Ceratophrys. Nature 130, 279.

https://doi.org/10.1038/130279b0

Parsons, C.W. (1932b). Report on penguin embryos collected during the Discovery investigations. Discovery Reports 6, 139-164.

Robertson, J.D. (1957). The habitat of the early vertebrates. Biological Reviews of the Cambridge Philosophical Society 32, 156-187. https://doi.org/10.1111/j.1469-185X.1957.tb01561. $\mathrm{x}$

Scottish Marine Biological Association (SMBA) (1939). Annual Report 1938-39. Millport.

Scottish Marine Biological Association (SMBA) (1940). Annual Report 1939-1940. Millport. 